\title{
ANALYSIS OF HUMAN BRADYKININ RECEPTOR GENE AND ENDOTHELIAL NITRIC OXIDE SYNTHASE GENE POLYMORPHISMS IN END-STAGE RENAL DISEASE AMONG MALAYSIANS
}

\author{
Vasudevan $\mathrm{R}^{1, \mathrm{a}^{*}}$, Ismail $\mathrm{P}^{2, \mathrm{a},{ }^{*}}$, Jaafar $\mathrm{NI}^{2}$, Mohamad NA ${ }^{1}$, Etemad E2, Wan Aliaa WS ${ }^{3}$, Eshkor $\mathrm{S}^{1}$ \\ ${ }^{a}$ These authors contributed equally to this article.
}

\begin{abstract}
*Corresponding Author: Professor Dr. Patimah Ismail, Department of Biomedical Sciences, Faculty of Medical and Health Science, Universiti Putra Malaysia, Serdang 43400, Selangor DE, Malaysia. Tel.: +60-3-8947-2314. Fax: +60-3-8943-6178. E-mail: patimashimail@gmail.com and Dr. Ramachandran Vasudevan, Institute of Gerontology, Universiti Putra Malaysia, Serdang, Selangor DE, 43400, Malaysia. Tel.: +60-3-8947-2752. Fax:+60-3-8947-2738. E-mail: vasuphd@gmail.com.
\end{abstract}

\begin{abstract}
The aim of this study was to determine the association of the c.894G $>$ T; p.Glu298Asp polymorphism and the variable number tandem repeat (VNTR) polymorphism of the endothelial nitric oxide synthase $(e N O S)$ gene and c. $181 \mathrm{C}>\mathrm{T}$ polymorphism of the bradykinin type 2 receptor gene $\left(B_{2} R\right)$ in Malaysian end-stage renal disease (ESRD) subjects.

A total of 150 ESRD patients were recruited from the National Kidney Foundation's (NKF)dialysis centers in Malaysia and compared with 150 normal healthy individuals. Genomic DNA was extracted from buccal cells of all the subjects. The polymerase chain reaction-restriction fragment length polymorphism (PCR-RFLP) method was carried out to amplify the products and the restricted fragments were separated by agarose gel electrophoresis. Statistical analyses were carried out using software where a level of $p<0.05$ was considered to be statistically significant.

The genotypic and allelic frequencies of the $B_{2} R$ gene (c.181C>T, 4b/a) and eNOS gene (c.894G>T) polymorphisms were not statistically significant
\end{abstract}

\footnotetext{
${ }^{1}$ Institute of Gerontology, Universiti Putra Malaysia, Serdang 43400, Selangor DE, Malaysia

${ }^{2}$ Genetic Research Group, Molecular Biology Unit, Department of Biomedical Science, Faculty of Medicine and Health Sciences, Universiti Putra Malaysia, Serdang 43400, Selangor DE, Malaysia

${ }^{3}$ Department of Medicine, Faculty of Medicine and Health Sciences, Universiti Putra Malaysia, Serdang 43400, Selangor DE, Malaysia
}

$(p>0.05)$ when compared to the control subjects. The $B_{2} R$ and $e N O S$ gene polymorphisms may not be considered as genetic susceptibility markers for Malaysian ESRD subjects.

Keywords: Bradykinin type 2 receptor $\left(B_{2} R\right)$ gene; Endothelial nitric oxide synthase (eNOS) gene; End-stage renal disease (ESRD); Polymorphism

\section{INTRODUCTION}

End-stage renal disease (ESRD) is also known as a stage of chronic renal disease in which renal replacement therapy, dialysis or kidney transplantation is needed to sustain life [1]. End-stage renal disease is a complex phenotype and multifactorial disease caused by both environmental and genetic factors [2]. Several studies have shown that genetic factors may also contribute to the development of ESRD $[3,4]$. Bradykinin $\mathrm{B}_{2}$ receptor $\left(B_{2} R\right)$ and the endothelial nitric oxide synthase (eNOS) genes have been proven to be candidate genes associated with ESRD $[5,6]$. Meta analysis studies showed that the candidate genes involved in the development of ESRD led to contradictory results in various populations [7]. This may be due to the difference of genetic predisposition causing this association of polymorphism with ESRD to differ between populations. In Malaysia, there is a lack of literature on the association of the bradykinin receptor and the eNOS gene polymorphisms with the development of ESRD. Taking this into account, 
we sought to determine the association of $B_{2} R$ and eNOS gene polymorphisms and the ESRD subjects in Malaysians.

\section{MATERIALS AND METHODS}

The study was approved by the Ethical Committee of the Faculty of Medicine and Health Science (RUGS project no. 91104) and permission was obtained from the National Kidney Foundation (NKF) of Malaysia. A total of 320 subjects were approached and 300 [ 150 patients from the NKF undergoing dialysis treatment and 150 unrelated healthy individuals, randomly selected by conducting health screening programs at various places in and around the Universiti Putra Malaysia (UPM) Serdang, Malaysia area], were recruited for this study; some subjects were excluded due to inconsistent genotyping results and extreme values. Written consent was obtained from all subjects who participated in this study and buccal cells were collected from ESRD subjects using cytology brushes. Genomic DNA was extracted to determine the genetic polymorphisms of the eNOS and $B_{2} R$ genes. The polymerase chain reaction-restriction fragment length polymorphism (PCR-RFLP) method was carried out for all subjects according to the available protocols [8,9]. All the amplified products were separated using $2.0 \%$ agarose gel electrophoresis and the gel was stained using Gel Red (Biotium, Hayward, CA, USA). The stained gel was visualized under UV light using an Alpha Imager (Alpha Innotech, San Leandro, CA, USA). Identical results were obtained when genotyping was performed on two separate occasions for $10.0 \%$ of the samples. All the statistical analyses were carried out using the Statistical Package for the Statistical Sciences (SPSS) (Chicago, IL, USA) software, version 18.0 for Microsoft Windows. A $p$ value of $<0.05$ was considered to be significant.

\section{RESULTS}

Clinical Characteristics of All Subjects. This study comprised 150 patients (87 males and $63 \mathrm{fe}$ males) and 150 controls (67 males and 90 females). The sex ratio was $51.3 \%$ males to $48.7 \%$ females. The ages of the ESRD patients ranged from 31 to 75 years old, with a mean age of $54.68 \pm 12.20$ years, compared to 25 to 74 years old, with a mean age of $45.82 \pm 13.39$ years in the controls. The mean serum creatinine ( $\mathrm{SCr}$ ) level for ESRD patients was $9.59 \pm 2.95$ compared to $0.62 \pm 0.23$ in the controls, suggesting that patients with a higher level of creatinine are more likely to develop ESRD. There were significant differences for age, creatinine level, systolic blood pressure (SBP), total cholesterol (TC) and triglyceride (TG) levels between ESRD subjects and controls $(p<0.05)$. Creatinine levels, as well as SBP, TC and TG levels in ESRD subjects were higher compared to control subjects. However, there were no significant differences observed in diastolic blood pressure (DBP), high-density lipoprotein (HDL) and low-density lipoprotein (LDL) between ESRD subjects and controls $(p>0.05)$.

Genotype and Allele Analysis. Table 1 shows the distribution of genotype and allele frequencies of the eNOS and $B_{2} R$ genes. There was no significant difference observed in both genotype and allele frequencies of the studied polymorphisms between ESRD and controls $(p>0.05)$. The $\mathrm{T}$ allele frequency of the c.894G $>\mathrm{T}$ gene polymorphism was not significantly different in patients $(37.67 \%)$ and control subjects $(37.33 \%)(p>0.05)$. The wild type $(4 \mathrm{~b} / \mathrm{b} ; 87.33 \%)$ genotype of variable number tandem repeat (VNTR) in intron 4 of the eNOS gene was dominant, followed by the heterozygous type (4b/a; $11.33 \%)$ and the least frequent was the mutant type $(4 \mathrm{a} / \mathrm{a} ; 1.33 \%)$ compared to $79.33,18.67$ and $2.0 \%$, in control subjects, respectively. The derived allele frequency of the $\mathrm{T}$ allele of $\mathrm{c} .181 \mathrm{C}>\mathrm{T}$ polymorphism was $2.0 \%$ in ESRD subjects compared to $1.0 \%$ in controls. There was no association found in the c. $181 \mathrm{C}>\mathrm{T}$ polymorphism of the $B_{2} R$ gene among ESRD and control subjects $(p>0.05)$.

\section{DISCUSSION}

Genetic polymorphisms of the $B_{2} R$ and eNOS genes might be involved in the development of ESRD as they were involved in the impairment of renal functions $[4,8]$. Several studies have been conducted to assess the association of the $B_{2} R$ and $e N O S$ polymorphisms with the risk of ESRD in several populations with contradictory results [9-11]. The c.181C $>$ T; p.Arg14Cys polymorphism in exon 2 of the $B_{2} R$ gene had a similar genotypic frequency in ESRD $(98.0 \%)$ and control subjects $(99.0 \%)$ and were well in accordance with the other studies $(p$ 
Table 1. Genotype and allele frequency of all three genetic polymorphisms.

\begin{tabular}{|c|c|c|c|c|}
\hline Gene Polymorphisms & Genotypes & $\operatorname{ESRD}(n=150) n(\%)$ & Controls $(n=150) n(\%)$ & p Value \\
\hline c. $894 \mathrm{G}>\mathrm{T}$ & $\begin{array}{l}\text { GG } \\
\text { GT } \\
\text { TT }\end{array}$ & $\begin{array}{c}45(30.00) \\
97(64.67) \\
8(5.33)\end{array}$ & $\begin{array}{c}45(30.00) \\
98(65.33) \\
7(4.67)\end{array}$ & $0.965^{\mathrm{a}}$ \\
\hline Alleles & $\begin{array}{l}\mathrm{G} \\
\mathrm{T}\end{array}$ & $\begin{array}{l}187(62.33) \\
113(37.67)\end{array}$ & $\begin{array}{l}188(62.67) \\
112(37.33)\end{array}$ & $0.933^{\mathrm{a}}$ \\
\hline OR $(95 \% \mathrm{CI})$ & \multicolumn{4}{|c|}{$0.6664(0.708-1.372)$} \\
\hline VNTR in intron 4 genotypes & $\begin{array}{l}4 b / b \\
4 b / a \\
4 a / a\end{array}$ & $\begin{array}{c}131(87.33) \\
17(11.33) \\
2(1.33)\end{array}$ & $\begin{array}{c}119(79.33) \\
28(18.67) \\
3(2.00)\end{array}$ & $0.177^{\mathrm{a}}$ \\
\hline Alleles & $\begin{array}{l}b \\
a\end{array}$ & $\begin{array}{c}279(93.00) \\
21(7.00)\end{array}$ & $\begin{array}{c}266(88.67) \\
34(11.33)\end{array}$ & $0.066^{\mathrm{a}}$ \\
\hline OR $(95 \% \mathrm{CI})$ & \multicolumn{4}{|c|}{$0.708(0.289-0.870)$} \\
\hline c. $181 \mathrm{C}>\mathrm{T}$ & $\begin{array}{l}\text { CC } \\
\text { CT } \\
\text { TT }\end{array}$ & $\begin{array}{c}144(96.00) \\
6(4.00) \\
0(0.00)\end{array}$ & $\begin{array}{c}148(98.00) \\
2(2.00) \\
0(0.00)\end{array}$ & $0.152^{b}$ \\
\hline Alleles & $\begin{array}{l}\mathrm{C} \\
\mathrm{T}\end{array}$ & $\begin{array}{c}294(98.00) \\
6(2.00)\end{array}$ & $\begin{array}{c}298(99.00) \\
2(1.00)\end{array}$ & $0.155^{\mathrm{b}}$ \\
\hline OR $(95 \% \mathrm{CI})$ & \multicolumn{4}{|c|}{$0.329(0.066-1.643)$} \\
\hline
\end{tabular}

OR: Odds ratio; $95 \% \mathrm{CI}$ : 95\% confidence interval.

${ }^{a}$ Data were evaluated by the Pearson $\chi^{2}$ test and were not significant $(p>0.05)$.

${ }^{\mathrm{b}}$ Data was analyzed excluding the TT genotype.

$>0.05$ ) [12]. Thus, the c. $181 \mathrm{C}>\mathrm{T}$ polymorphism was not functionally significant in Malaysian ESRD subjects. Studies had suggested that the c.894G $>$ T polymorphism may be a predisposing factor in hypertension, diabetes and ESRD $[13,14]$.

In this study, the $\mathrm{T}$ allele frequency for ESRD and control subjects was 37.67 and $37.33 \%$, respectively, and were not significantly different. The eNOS 4a allele may have a role in the development of chronic renal failure [11]. The carriers of the $4 \mathrm{a}$ allele were found to be less frequent among ESRD cases compared with controls ( $7.0 \mathrm{vs.} 11.3 \%$ ) but the difference did not reach statistical significance. These findings were not in agreement with other populations $[6,11]$. The results found in this study were contradictory to the other association studies in several populations, which might be due to population stratification caused by ethnic differences, sampling bias, environmental factors and racial differences that may contribute to the contradictory results. This study did not match either with age or gender be- tween case and control subjects, and all the subjects were not homogenous. Further studies are recommended to confirm the association of these and the other polymorphisms in the eNOS and $B_{2} R$ genes in Malaysians subjects with ESRD. In conclusion, the results of this study suggest that the c.181C $>\mathrm{T}$ polymorphism of the $B_{2} R$ gene, $4 \mathrm{~b} / \mathrm{a}$ and c. $894 \mathrm{G}>\mathrm{T}$ polymorphisms in the eNOS gene, were not associated with ESRD susceptibility in Malaysians.

\section{ACKNOWLEDGMENTS}

The authors would like to extend their gratitude to the NFK Dialysis centers and all the volunteers involved in this study. This study was supported by the Research University Grant Scheme (RUGS Grant No: 9300345).

Declaration of Interest. The authors report no conflicts of interest. The authors alone are responsible for the content and writing of this article. 


\section{REFERENCES}

1. Eddy AA. Progression in chronic kidney disease. Adv Chronic Kidney Dis. 2005; 12(4): 353-365.

2. Zolezzi M. Management of dyslipidemia in renal disease and transplantation. Saudi J Kidney Dis Transpl. 2006; 17(2): 129-136.

3. Eikmans M, Aben JA, Koop K, Baelde HJ, de Heer E, Bruijn JA. Genetic factors in progressive renal disease: the good ones, the bad ones and the ugly ducklings. Nephrol Dial Transpl. 2006; 21(2): 257-260.

4. Satko SG, Freedman BI, Moossavi S. Genetic factors in end-stage renal disease. Kidney Int Suppl. 2005 (94): S46-S49.

5. Braun A, Kammerer S, Bohme E, Muller B, Roscher AA. Identification of polymorphic sites of the human bradykinin $\mathrm{B} 2$ receptor gene. Biochem Biophys Res Commun. 1995; 211(1): 234-240.

6. Nagase S, Suzuki H, Wang Y, Kikuchi S, Hirayama A, Ueda A, et al. Association of eNOS gene polymorphisms with end stage renal diseases. Mol Cell Biochem. 2003; 244(1-2): 113-118.

7. Yun Z, Yu-Ping Y, Zong-Wu T, Yang S, Fang Y, Fang S. Association of endothelial nitric oxide synthase gene polymorphisms with end-stage renal disease: a systematic review and metaanalysis. Ren Fail. 2014; 36(6): 987-993.

8. Zychma MJ, Gumprecht J, Trautsolt W, Szydlowska I, Grzeszczak W. Polymorphic genes for kinin receptors, nephropathy and blood pressure in type 2 diabetic patients. Am J Nephrol. 2003; 23(2): 112-116.
9. Zhou TB, Yin SS. Association of endothelial nitric oxide synthase Glu298Asp gene polymorphism with the risk of end-stage renal disease. Ren Fail. 2013; 35(4): 573-578.

10. Maltais I, Bachvarova M, Maheux P, Perron P, Marceau F, Bachvarov D. Bradykinin B2 receptor gene polymorphism is associated with altered urinary albumin/ creatinine values in diabetic patients. Can J Physiol Pharmacol. 2002; 80(4): 323-327.

11. Buraczynska M, Ksiazek P, Zaluska W, Nowicka T, Ksiazek A. Endothelial nitric oxide synthase gene intron 4 polymorphism in patients with end-stage renal disease. Nephrol Dial Transpl. 2004; 19(9): 2302-2306.

12. Bachvarov DR, Landry M, Pelletier I, Chevrette $\mathrm{M}$, Betard C, Houde I, et al. Characterization of two polymorphic sites in the human kinin B1 receptor gene: altered frequency of an allele in patients with a history of end-stage renal failure. J Am Soc Nephrol. 1998; 9(4): 598-604.

13. Tang FY, Liu FY, Xie XW. Association of angiotensin-converting enzyme and endothelial nitric oxide synthase gene polymorphisms with vascular disease in ESRD patients in a Chinese population. Mol Cell Biochem. 2008;319(1-2):33-9.

14. Li J, Cun Y, Tang WR, Wang Y, Li SN, Ouyang $\mathrm{HR}$, et al. Association of eNOS gene polymorphisms with essential hypertension in the Han population in southwestern China. Genet Molec Res. 2011; 10(3): 2202-2212. 